\title{
African partnerships for patient safety: a catalyst for change in Ethiopia
}

\author{
J Hightower ${ }^{*}$, M Fahmi $^{2}$, M Gashaw $^{3}$, A Derso $^{4}$ \\ From International Conference on Prevention \& Infection Control (ICPIC 2011) \\ Geneva, Switzerland. 29 June - 2 July 2011
}

\section{Introduction / objectives}

African Partnerships for Patient Safety (APPS) stimulated such national actionNational action on infection control in Ethiopia - key steps are outlined.

\section{Methods}

As the result of patient safety sensitization presentations given about the APPS partnership between Gondar Hospital and Leicester Hospital, the Federal Ministry of Health (FMOH) was inspired to begin an extensive pilot program of its own. Technical support was given to the $\mathrm{FMOH}$ to clarify specific short and long term patient safety priorities. Existing FMOH infrastructure and partners were identified to provide a platform for training and monitoring \& evaluation.

\section{Results}

Patient safety was established as a FMOH priority in the 5 year plan (2010-2015) with specific activities:

1. An Ethiopian FMOH National Patient Safety Program was established prioritizing 4 patient safety action areas in 3 pilot university hospitals. A FMOH technical working group was re-invigorated to cover both patient safety and infection control.

2. FMOH hospital management guidelines revised to include patient safety action areas.

3. National Nursing Standards of Care training material revised to include patient safety.

4. National production of alcohol based hand rub was initiated.

\section{Conclusion}

APPS catalyzed national patient safety action in Ethiopia, resulting in a rapid nationally led integration of patient safety strategy, policy, training, and harmonization of

${ }^{1}$ Patient Safety, World Health Organization, Addis Ababa, Ethiopia Full list of author information is available at the end of the article support activities. This potentially sustainable national patient safety program can be replicated elsewhere.

\section{Disclosure of interest}

None declared.

\section{Author details}

${ }^{1}$ Patient Safety, World Health Organization, Addis Ababa, Ethiopia. ${ }^{2} \mathrm{HIV}$, WHO, Adiss Ababa, Ethiopia. ${ }^{3}$ Patient Safety, Gondar University Hospital, Gondar, Ethiopia. ${ }^{4}$ Medical Services, Ministry of Health, Addis Ababa, Ethiopia.

Published: 29 June 2011

\section{doi:10.1186/1753-6561-5-S6-P322}

Cite this article as: Hightower et al:: African partnerships for patient safety: a catalyst for change in Ethiopia. BMC Proceedings 2011 5(Suppl 6):P322.
Submit your next manuscript to BioMed Central and take full advantage of:

- Convenient online submission

- Thorough peer review

- No space constraints or color figure charges

- Immediate publication on acceptance

- Inclusion in PubMed, CAS, Scopus and Google Scholar

- Research which is freely available for redistribution
C Biomed Central 